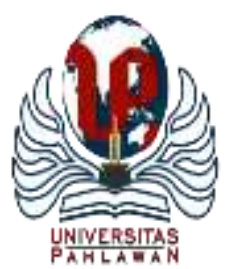

Edukatif : Jurnal Ilmu Pendidikan Volume 4 Nomor 1 Tahun 2022 Halm 795 - 802

EDUKATIF: JURNAL ILMU PENDIDIKAN

Research \& Learning in Education

https:/ledukatif.org/index.php/edukatif/index

\title{
Penerapan Model SAVI (Somatic, Audiotory, Visualition, Intellectual) dalam Meningkatkan Keterampilan Berpikir Kreatif Mahasiswa pada Pembelajaran Daring Prodi Administasi Rumah Sakit
}

\author{
Erpidawati $^{1 凶}$, Silvia Adi Putri ${ }^{2}$ \\ Universitas Muhammadiyah Sumatera Barat, Indonesia ${ }^{1,2}$ \\ E-mail : $\underline{\text { erpidawati821@ gmail.com }}^{1}$, silviaadiputri86@ gmail.com ${ }^{2}$
}

\begin{abstract}
Abstrak
Tujuan penelitian Pengaruh model SAVI (somatic, audiotory, visualition, intellectual) terhadap keterampilan berpikir kreatif berdasarkan hasil belajar mahasiswa semester IV Program Studi Administrasi Rumah Sakit. Metodologi Penelitian Jenis Penelitian kuantitatif dalam bentuk Quasi Eksprimental Design. Sampel dalam penelitian ini teknik simple random sampling. Subjek pada penilitian mahasiswa di semester IV. Teknik pengumpulan data tes dan kuisoner, teknik analisis data untuk menguji normalitas data, homogenitas hipotesis. Hasil Penelitian kemampuan berpikir kreatif mahasiswa yang belajar menggunakan model SAVI dalam pembelajaran daring lebih baik daripada kemampuan berpikir kreatif mahasiswa yang belajar menggunakan model ekspositori. Kemampuan berpikir kreatif mahasiswa dengan hasil belajar tinggi yang belajar dengan menggunakan pendekatan SAVI lebih baik daripada kemampuan berpikir kreatif mahasiswa dengan hasil belajar tinggi yang belajar dengan model ekspositori.Kemampuan berpikir kreatif mahasiswa dengan hasil belajar rendah yang belajar dengan menggunakan pendekatan SAVI lebih baik daripada kemampuan berpikir kreatif mahasiswa dengan hasil belajar rendah yang belajar dengan model ekspositori. Tidak terdapat interaksi antara pendekatan SAVI dan hasil belajar mahasiswa dalam mempengaruhi kemampuan berpikir kreatif mahasiswa.
\end{abstract}

Kata Kunci: Berpikir Kreatif, Mode SAVI.

\section{Abstract}

Research objective The effect of the SAVI model (somatic, audiotory, visualition, intellectual) on creative thinking skills based on student learning outcomes in the fourth semester of the Hospital Administration Study Program. Research Methodology This type of research is quantitative in the form of Quasi Experimental Design. The sample in this study was simple random sampling technique. Subjects in student research in the fourth semester. Test and questionnaire data collection techniques, data analysis techniques to test data normality, hypothesis homogeneity. The results of the study, the creative thinking ability of students who learn to use the SAVI model in online learning is better than the creative thinking ability of students who learn to use the expository model. The creative thinking ability of students with high learning outcomes who study using the SAVI approach is better than the creative thinking abilities of students with high learning outcomes who study with the expository model. creative students with low learning outcomes who study with the expository model. There is no interaction between the SAVI approach and student learning outcomes in influencing students' creative thinking skills

Keywords: Creative Thinking, SAVI Mode

Copyright (c) 2022 Erpidawati, Silvia Adi Putri

$\triangle$ Corresponding author

Email : erpidawati821@gmail.com

DOI $\quad$ : https://doi.org/10.31004/edukatif.v4i1.1875 
796 Penerapan Model SAVI (Somatic, Audiotory, Visualition, Intellectual) dalam Meningkatkan Keterampilan Berpikir Kreatif Mahasiswa pada Pembelajaran Daring Prodi Administasi Rumah Sakit - Erpidawati, Silvia Adi Putri

DOI: https://doi.org/10.31004/edukatif.v4i1.1875

\section{PENDAHULUAN}

Pendidikan bertujuan untuk mengembangkan potensi mahasiswa agar menjadi manusia yang beriman dan bertaqwa kepada Tuhan Yang Maha Esa, berakhlak mulia, sehat, berilmu, cakap, kreatif, mandiri, dan menjadi warga negara yang demokrasi serta bertanggung jawab (Perpres, tentang Sistim Pendidikan Nasional Tahun 2003). Guna menghasilkan lulusan yang kompetitif diperlukan pembaharuan dalam pengelolaan pendidikan. Salah satunya adalah faktor interaksi dosen dengan mahasiswa. Interaksi dosen dan mahasiswa dalam kaitannya dengan penyajian pengalaman pembelajaran, kurikulum memiliki posisi sentral. Dunia pendidikan pada saat sekarang selalu mengalami perkembangan dan perubahan ke arah penyempurnaan kurikulum. Khusus diperguruan tinggi kurikulum yang digunakan berdasarkan KKNI telah dilaksanakan dengan tujuan menyetarakan kualifikasi capaian pembelajaran yang diperoleh memalui pendidikan formal, non formal dan informal atau pengalaman kerja mengembangkan metode dan sistim pengakuan kualifkasi tenaga kerja dari Negara lain yang akan bekerja di Indonesia. Pandemi Covid 19 merubah teknik dan pola pembelajaran yang dilakukan, yang selama ini pembelajaran dilakukan secara tatap muka, namun saat ini proses pembelajaran masih dilaksanakan secara daring, didalam proses pembelajaran yang dilakukan dengan tatap muka.

Namun pada kenyataannya, harapan tersebut belum dapat terwujud secara maksimal. Pembelajaran daring yang dilakukan belum maksimal masih dominan menggunakan pembelajaran dengan metode ceramah yang semua pembelajaran hanya terpusat pada dosen tanpa mengaktifkan mahasiswa sehingga pembelajaran masih kurang bermakna bagi mahasiswa. Kondisi sekarang ini pembelajaran yang berlangsung secara daring masih didominasi pembelajaran dengan metode ceramah. Pembelajaran yang demikian ditandai dengan peran dominan pada dosen, mahasiswa dipandang sebagai obyek dan belajar diartikan sebagai transfer of knowledge. Kesadaran perlunya strategi dalam pembelajaran didasarkan adanya kenyataan bahwa sebagaian besar mahasiswa kurang mampu menghubungkan antara yang mahasiswa pelajari dengan bagaimana pemanfaatannya dalam kehidupan nyata. Hal ini karena hasil belajar yang mahasiswa peroleh hanyalah merupakan sesuatu yang abstrak (Febrianti et al., 2016).

Berdasarkan observasi pada tanggal 4-15 Juni 2020 di pada pembelajaran yang sudah menerapkan KKNI. Kenyataan yang terjadi selama observasi guru menjelaskan materi namun mahasiswa kurang mampu mengidentifikasi argumen-argumen. mahasiswa kurang pengalaman langsung pada suatu yang nyata sebagai dasar memahami yang abstrak sehingga mahasiswa kurang mampu mengidentifikasi mana logika-logika yang keliru. Mahasiswa dalam pembahasan diskusi kelompok kurang mampu mengekspresikan diri untuk memberanikan diri tampil kedepan kelas menyajikan hasil diskusi kelompoknya. Sesuai dengan pernyataan ini bahwa keterampilan berpikir kreatif mahasiswa yang belum berkembang dengan baik salah satunya disebabkan oleh pembelajaran di sekolah yang kurang memberdayakan keterampilan berpikir keatif mahasiswa. Kenyataan seperti inilah yang seharusnya kemampuan berpikir kreatif guru untuk melakukan pembaharuan pada pembelajaran. Inovasi (pembaharuan) perlu dilakukan agar tercipta suasana belajar yang menyenangkan, menarik, membuat mahasiswa terfokus pada pembelajaran, mampu menciptakan suasana belajar yang kondusif serta bermuara pada terciptanya suasana belajar yang optimal (Sulistiono \& Yuni Sri Rahayu, 2014), (Handoko, 2017).

Salah satunya adalah melalui pendekatan "SAVI" (Somatic, Auditory, Visualition, Intelectual). Somatis adalah dengan menyajikan materi yang bisa melibatkan mahasiswa untuk lebih aktif dengan seluruh kemampuan yang mereka miliki, bukan hanya sekedar aktif dalam bertanya tetapi aktif juga dalam hal mencari tahu ilmu tersebut. Auditori belajar dengan cara mendengarkan dan berbicara dengan hal ini diharapkan mahasiswa bisa menanyakan hal-hal yang belum mereka ketahui dari penjelasan yang dijabarkan oleh guru. Visual mengamati dan memperhatikan ilmu yang diajarkan. Intelektual. Belajar dengan 
797 Penerapan Model SAVI (Somatic, Audiotory, Visualition, Intellectual) dalam Meningkatkan Keterampilan Berpikir Kreatif Mahasiswa pada Pembelajaran Daring Prodi Administasi Rumah Sakit - Erpidawati, Silvia Adi Putri

DOI: https://doi.org/10.31004/edukatif.v4i1.1875

memecahkan masalah dan memikirkannya agar masalah dapat terpecahkan (Ainia et al., 2012). Mahasiswa dalam proses perkuliahan diperguruan tinggi akan ditentukan oleh hasil belajar, parameter keberhasilan dalam belajar dapat dilihat dari nilai akademik atau indeks prestasi (IP) (Erpidawati \& Susanti, 2019), (Daharnis, 2019), (Haruminati et al., 2016).

Unsur-unsur SAVI sangat berpotensi untuk melatih keterampilan karena di dalam pembelajaran SAVI tidak hanya menggunakan kemampuan berpikir (minds- on), tetapi juga memanfaatkan gerak tubuh (hands-on). Pendekatan SAVI juga berpotensi mengatasi keragaman tipe belajar mahasiswa yang ada di kelas. Masing- masing mahasiswa dalam suatu kelas pada dasarnya memiliki kecenderungan gaya belajar berbeda-beda dalam memahami materi pelajaran. Melalui pendekatan SAVI mahasiswa dapat mengembangkan keterampilan proses sains mahasiswa dengan gaya belajar mereka seperti somatic, auditory, visual, dan intelektual. Berdasarkan uraian tersebut, maka perlu dilakukan suatu penelitian yang mengkaji pengaruh model SAVI (Somatic, Audiotory, Visualition, Intellectual) terhadap keterampilan berpikir kreatif berdasarkan hasil belajar mahasiswa (Haruminati et al., 2016), (Rintonga, 2019), (Ahmad et al., 2021).

\section{METODOLOGI PENELITIAN}

Jenis Penelitian Berdasarkan permasalahan dan tujuan yang ingin dicapai, maka penelitian ini menggunakan pendekatan kuantitatif dalam bentuk Quasi Eksprimental Design. Observasi dilakukan sebanyak 2 (dua) kali yaitu sebelum eksperimen dan sesudah eksperimen, yaitu: kondisi eksperimen dengan model pembelajaran SAVI dan kondisi komparasi (kontrol) dengan hasil belajar mahasiswa,Tempat dan Waktu Penelitian ini dilakukan pada mahasiswa semester IV prodi Administrasi Rumah Sakit Populasi Populasi pada penelitian ini adalah seluruh mahasiswa semester IV yang terdaftar pada semester genap 2020/2021. Sampel dalam penelitian ini peneliti mengambil subjek dengan menggunakan teknik simple random sampling. Subjek pada penilitian ini prosedur yang sistematis dapat digunakan untuk mencapai tujuan penelitian. Secara umum, prosedur penelitian dibagi menjadi tiga tahap yaitu tahap persiapan, tahap pelaksanaan, dan tahap penelitian. Teknik analisis data Analisis data bertujuan untuk menguji hipotesis yang diajukan, apakah diterima atau ditolak. Sebelum melakukan uji hipotesis terlebih dahulu dilakukan uji normalitas dan uji homogenitas variansi terhadap kelas sampel, untuk melihat apakah sampel berdistribusi normal atau tidak serta apakah kedua kelompok data mempunyai variansi yang homogen atau tidak.

\section{HASIL PENELITIAN}

Kemampuan berpikir kreatif mahasiswa yang belajar menggunakan model SAVI lebih baik dari pada kemampuan berpikir kreatif mahasiswa yang belajar menggunakan model ekspositori hipotesis yang berbunyi Kemampuan berpikir kreatif mahasiswa yang belajar menggunakan model SAVI lebih baik dari pada kemampuan berpikir kreatif mahasiswa yang belajar menggunakan model ekspositori yang diajarkan dengan pembelajaran konvensional hasil temuan menggambarkan bahwa kemampuan berpikir kreatif memperoleh

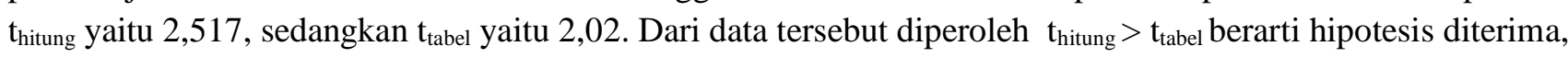
artinya kemampuan berpikir kreatif mahasiswa yang belajar menggunakan model SAVI lebih baik dari pada kemampuan berpikir kreatif mahasiwa yang belajar menggunakan model ekspositori.

Temuan di atas sejalan dengan penelitian (Ahmad et al., 2021) kemandirian belajar dibandingkan model pembelajaran AIR. Kesimpulan dari penelitian ini adalah tingkat pemahaman konsep pada mahasiswa yang diberi perlakuan model pembelajaran SAVI dibandingkan mahasiswa yang diberi perlakuan model pembelajaran AIR memiliki perbedaan yang signifikan. Proses pembelajaran merupakan proses pengembangan keseluruhan dari interaksi dan pengalaman belajar. Proses pembelajaran tidak ditentukan oleh 
798 Penerapan Model SAVI (Somatic, Audiotory, Visualition, Intellectual) dalam Meningkatkan Keterampilan Berpikir Kreatif Mahasiswa pada Pembelajaran Daring Prodi Administasi Rumah Sakit - Erpidawati, Silvia Adi Putri

DOI: https://doi.org/10.31004/edukatif.v4i1.1875

selera guru, akan tetapi sangat ditentukan oleh mahasiswa itu sendiri, itu yang disebut membelajarkan mahasiswa (Sanjaya,2016). Menyadari pentingnya melibatkan mahasiswa dalam proses pembelajaran, maka dalam pembelajaran telah dilaksanakan penelitian yang menggunakan model pembelajaran yang dapat membangkitkan kreativitas mahasiswa yaitu dengan penerapan model pembelajaran somatic, auditory, visual, dan intelektual (SAVI). Pada kelas kontrol yaitu kelas mahasiswa kelas IV juga dilakukan penelitian secara metode eksipositori. Hal ini bertujuan untuk melihat pengaruh model pembelajaran somatic, auditory, visual, dan intelektual (SAVI) dalam meningkatkan kemampuan berpikir kreatifmahasiswa. Hasil penelitian menunjukkan bahwa kemampuan berpikir kreatifmahasiswa di dalam belajar meningkat hasil belajar mahasiswa dengan menggunakan model pembelajaran somatic, auditory, visual, dan intelektual (SAVI) pada kelas eksperimen, secara eksipositori di kelas kontrol. Dengan memperhatian kemampuan awal mahasiswa memberikan dampak positif terhadap kemampuan berpikir kreatifmahasiswa. Kemampuan awal mahasiswa pada proses pembelajaran sangat penting bagi guru agar dapat memberikan pelajaran yang tepat, tidak terlalu sulit dan tidak terlalu mudah (Hazal Fitri, 2015).

Hal itu hanya terjadi di kelas eksperimen, berbeda pada kelas kontrol mahasiswa lebih banyak diam dan mengandalkan teman lainnya, karena kurangnya pemahaman terhadap materi yang menyebabkan mahasiswa tidak tahu apa yang ingin ditanya dan tidak tahu apa yang akan dijawab apabila ada yang bertanya atau guru bertanya. Sehingga perbedaan hasil kemampuan berpikir kreatif mahasiswa kelas eksperimen dengan hasil kemempuan berpikir kreatifmahasiswa kelas kontrol. Ilmu pengetahuan terpadu dalam pembelajaran diperlukan bagi guru untuk merencanakan, merancang, dan mengimplementasikan proses pembelajaran secara mutlak (Fitria, 2019). Pembelajaran SAVI menganut aliran ilmu kognitif modern yang menyatakan belajar yang paling baik adalah melibatkan emosi, seluruh tubuh, semua indera, dan segenap kedalaman serta keluasan pribadi, menghormati gaya belajar individu lain dengan menyadari bahwa orang belajar dengan caracara yang berbeda. Mengkaitkan sesuatu dengan hakikat realitas yang nonlinear, nonmekanis, kreatif dan hidup.

Kemampuan berpikir kreatif mahasiswa dengan hasil belajar tinggi yang belajar dengan menggunakan pendekatan SAVI lebih baik daripada kemampuan berpikir kreatif mahasiswa dengan hasil belajar tinggi yang belajar dengan model ekspositori Hipotesis yang berbunyi bahwa Kemampuan berpikir kreatif mahasiswa dengan hasil belajar tinggi yang belajar dengan menggunakan pendekatan SAVI lebih baik daripada kemampuan berpikir kreatif mahasiswa dengan hasil belajar tinggi yang belajar dengan model ekspositori hasil uji $\mathrm{t}$ kemampuan berpikir kreatifmahasiswa berkemampuan awal tinggi memperoleh $\mathrm{t}_{\text {hitung }}$ yaitu 5,01 sedangkan $t_{\text {tabel }}$ yaitu 2,13. Dari data tersebut diperoleh $t_{\text {hitung }}>t_{\text {tabel }}$ berarti hipotesis diterima, yaitu terdapat pengaruh Kemampuan berpikir kreatif mahasiswa dengan hasil belajar tinggi yang belajar dengan menggunakan pendekatan SAVI lebih baik daripada kemampuan berpikir kreatif mahasiswa dengan hasil belajar tinggi yang belajar dengan model ekspositori.

Berdasarkan hasil penelitian model pembelajaran SAVI berkemampuan awal tinggi pada kelas eksperimen lebih tinggi dari mahasiswa berkemampuan awal tinggi di kelas kontrol dengan pembelajaran secara eksipositori. Begitu juga pada mahasiswa berkemampuan awal rendah pada kelas eksperimen lebih baik dari mahasiswa berkemampuan awal rendah pada kelas kontrol. Hail ini disebabkan model pembelajaran model SAVI pada kelas eksperimen memberikan waktu lebih banyak bagi mahasiswa untuk berpikir memahami materi dan menyelesaikan soal sesuai kemampuan awal secara individu. Unsur-unsur SAVI sangat berpotensi untuk melatih keterampilan mahasiswa karena di dalam pembelajaran SAVI tidak hanya menggunakan kemampuan berpikir (minds- on), tetapi juga memanfaatkan gerak tubuh (handson). Pendekatan SAVI juga berpotensi mengatasi keragaman tipe belajar mahasiswa yang ada di kelas. Masing - masing mahasiswa dalam suatu kelas pada dasarnya memiliki kecenderungan gaya belajar berbeda-beda dalam memahami materi pelajaran. Melalui pendekatan SAVI mahasiswa dapat 
799 Penerapan Model SAVI (Somatic, Audiotory, Visualition, Intellectual) dalam Meningkatkan Keterampilan Berpikir Kreatif Mahasiswa pada Pembelajaran Daring Prodi Administasi Rumah Sakit - Erpidawati, Silvia Adi Putri

DOI: https://doi.org/10.31004/edukatif.v4i1.1875

mengembangkan keterampilan proses sains mahasiswa dengan gaya belajar mereka seperti somatic, auditory, visual, dan intelektual (Putri et al., 2018).

Perbedaan pendekatan pembelajaran SAVI dengan model pembelajaran ekspositori dalam pembelajaran menjadi dasar kerangka berpikir dalam pengembangan penelitian ini. Pembelajaran yang menggunakan model pembelajaran ekspositori merupakan pembelajaran yang berpusat pada guru sehingga guru merupakan satu-satunya sumber belajar dan penentu jalannya proses pembelajaran, dalam hal ini model pembelajaran ekspositori tidak dapat memberikan akses informasi belajar yang luas sehingga mahasiswa tidak dapat berkembang secara mandiri, untuk mengaktualisasikan pengetahuan atau pengalaman yang telah dimilikinya. Menerapkan model SAVI, mahasiswa yang memiliki hasil belajar tinggi dapat dengan mudah menguasai pelajaran yang sedang dipelajari, karena meraka terbantu dengan adanya kegiatan eksplorasi dimana guru memberikan stimulus berupa aktivitas dan tugas-tugas seperti melalui demontrasi/penelusuran terhadap suatu permasalahan yang menunjukkan data dan fakta yang terkait dengan konsepsi yang akan dipelajari. Dengan demikian mahasiswa tertantang untuk menemukan sendiri konsep-konsep yang sedang dipelajari. Kondisi ini membuat mereka semakin mudah meningkatkan pemahamannya sehingga pada akhirnya dapat meningkatkan kemampuan berpikir kreatif mahasiswa. Mahasiswa dengan lancar menjelaskan kesimpulan materi, tetapi penjelasannya tidak didasarkan pada kesimpulan materi atau berdasarkan hasil pemikirannya sendiri (Rintonga, 2019).

Torrance dalam Failsaisme (2008:109) berpikir kreatif merupakan sebuah proses yang melibatkan unsur-unsur orisinalitas, kelancaran, fleksibilitas, dan elaborasi. Berpikir kreatif merupakan salah sebuah proses menjadi sensitif atau sadar terhadap masalah-masalah, kekurangan, dan celah-celah di dalam pengetahuan yang untuknya tidak ada solusi yang dipelajari, membawa serta informasi, mencari solusi-solusi, menduga, menciptakan alternatif untuk penyelesaian masalah, menyempurnakan dan akhirnya mengkomunikasikan hasil - hasilnya. Penggunaan model SAVI untuk mahasiswa yang hasil belajar rendah juga dapat meningkatkan pemahamannya terhadap konsep-konsep yang telah dipelajari. Mereka semakin tertantang dengan mengikuti tahapan-tahapan yang telah ditentukan secara terstruktur oleh guru. Tahapantahapan yang tidak menyulitkan bagi mahasiswa membuat mereka dengan hasil belajar rendah bersemangat dalam belajar ditambah lagi dengan motivasi yang oleh guru. Hal ini ini akan bedapat meningkatkan kemampuan berpikir kreatif mahasiswa, karena meraka dapat menemukan konsep-konsep baru dari analisa sendiri dan ini akan berpengaruh terhadap pemahaman materi yang dipelajari.

Perbedaan Kemampuan berpikir kreatif mahasiswa dengan hasil belajar rendah yang belajar dengan menggunakan pendekatan SAVI lebih baik daripada kemampuan berpikir kreatif mahasiswa dengan hasil belajar rendah yang belajar dengan model ekspositori hipotesis yang berbunyi kemampuan berpikir kreatif mahasiswa dengan hasil belajar rendah yang belajar dengan menggunakan pendekatan SAVI lebih baik daripada kemampuan berpikir kreatif mahasiswa dengan hasil belajar rendah yang belajar dengan model ekspositori hasil uji t kemampuan berpikir kreatif mahasiswa berkemampuan awal rendah memperoleh $t_{\text {hitung }}$ yaitu 3,571, sedangkan $t_{\text {tabel }}$ yaitu 2,13. Dari data tersebut diperoleh $t_{\text {hitung }}>t_{\text {tabel }}$ berarti hipotesis diterima, yaitu terdapat pengaruh Kemampuan berpikir kreatif mahasiswa dengan hasil belajar rendah yang belajar dengan menggunakan pendekatan SAVI lebih baik daripada kemampuan berpikir kreatif mahasiswa dengan hasil belajar rendah yang belajar dengan model ekspositori. Hasil temuan di atas mengambarkan bahwa kemampuan berpikir kreatifmahasiswa kemampuan rendah tidak lebih baik atau sama-sama tidak berpengaruh terhadap kemampuan awal rendah kelas kontrol menggunakan metode eksipositori, (Novelti et al., 2018).

Menurut Susanto (2013:115) berpikir kreatif adalah suatu cara membangun ide yang dapat diterapkan dalam kehidupan. Proses kreatif akan muncul bila ada stimulus. Proses kreatif tersebut dirangkum dalam lima tahap, yaitu : stimulus, eksplorasi, perencanaan, aktivitas dan review (Handoko, 2017), dalam penelitiannya menemukan bahwa mahasiswa yang memiliki kreativitas yang tinggi cenderung lebih mandiri, mengusahakan 
800 Penerapan Model SAVI (Somatic, Audiotory, Visualition, Intellectual) dalam Meningkatkan Keterampilan Berpikir Kreatif Mahasiswa pada Pembelajaran Daring Prodi Administasi Rumah Sakit - Erpidawati, Silvia Adi Putri

DOI: https://doi.org/10.31004/edukatif.v4i1.1875

perubahan dalam lingkungannya, dan relasi interpersonalnya lebih terbuka dan aktif. Berikut dipaparkan perilaku anak kreatif yang memiliki tingkat intelegensi tinggi, sebagai berikut : (a) Aktif berpikir yang ditandai dengan rasa ingin tahu yang besar serta cepat tanggap dalam menyelesaikan persoalan, (b) Hati-hati dalam megambil suatu tindakan, (c) Bersemangat dalam memecahkan masalah, (d) Berusaha untuk menjadi lebih baik dari waktu ke waktu, sehingga selalu ingin melakukan hal yang baru dan (e) Memiliki sensitivitas yang tinggi sehingga mudah membaca peluang yang ada.Model SAVI merupakan suatu pendekatan pembelajaran dengan cara menggabungkan gerakan fisik dengan aktivitas intelektual dan penggunaan semua alat indera. Unsur-unsur yang terdapat dalam "SAVI" adalah somatik, auditori, visual dan intelektual. Keempat unsur ini harus ada dalam peristiwa pembelajaran, sehingga belajar bisa optimal. Berdasarkan uraian diatas tentang perbedaan model SAVI dan model pembelajaran ekspositori dapat dijadikan kerangka konseptual bahwa pendekatan SAVI memiliki kontribusi yang tinggi terhadap kemampuan berpikir kreatif mahasiswa.

Interaksi antara Model Pembelajaran SAVI dan Hasil Belajar terhadap Kemampuan Berpikir Kreatif mahasiswa hipotesis yang berbunyi bahwa terdapat interaksi pembelajaran dan kemampuan berpikir kreatif dengan dengan hasil belajar mahasiswa hasil temuan menggambarkan bahwa interaksi A (Model SAVI) x B (Kemampuan Awal berfikir kreatif), Fh =0,262 dan F0,05(2,24) = 3,15 karena $0.262<3,15$. Sehingga Ho diterima dan $\mathrm{H}_{\mathrm{I}}$ diterima, dengan demikian dapat disimpulkan terdapat tidak terdapat interaksi antara model pembelajaran SAVI dengan hasil belajar sisa. Pada kelas eksperimen mahasiswa berpartisipasi langsung dalam proses pembelajaran karena dalam model pembelajaran SAVI menuntut mahasiswa menuntut mahasiswa penerapan model SAVI berdampak baik terhadap keaktifan belajar mahasiswa. Mahasiswa merasa tertantang untuk mendalami materi dengan melakukan kegiatan-kegiatan belajar yang telah ditentukan guru. Adapun kegitan yang dilakukan pada saat penerapan pendekatan pembelajaran SAVI, dimulai dengan menghadapkan mahasiswa ke dalam suatu permasalahan nyata atau disimulasikan yang menantang, sehingga mahasiswa termotivasi untuk menyelesaikannya karena dapat dilihat dari berbagai sudut pandang. Mahasiswa dengan hasil belajar tinggi dapat meningkatkan kemampuan berpikir kreatifnya karena mahasiswa dapat mengeksplorasi pengetahuan dengan cara mengkoneksikan serta pengintekgrasian pengetahuan yang ia miliki dalam menyelesaikan permasalahan yang dihadapi secara kelompok maupun secara individu (Dores et al., 2020).

Menurut (Shoimin, 2016), SAVI singkatan dari Somatic, Auditori, Visualition dan Intellectual. Pembelajaran SAVI adalah pembelajaran yang menekankan bahwa belajar haruslah memanfaatkan semua alat indra yang dimiliki mahasiswa. Teori yang mendukung pembelajaran SAVI adalah Accelerated Learning, teori otak kanan/kiri; pilihan modalitas (visual, auditorial dan kinestetik); teori kecerdasan ganda; pendidikan (holistic) menyeluruh; belajar berdasarkan pengalaman; belajar dengan simbol. Pembelajaran SAVI menganut aliran ilmu kognitif modern yang menyatakan belajar yang paling baik adalah melibatkan emosi, seluruh tubuh, semua indera, dan segenap kedalaman serta keluasan pribadi, menghormati gaya belajar individu lain dengan menyadari bahwa orang belajar dengan cara-cara yang berbeda (Rintonga, 2019). Mengkaitkan sesuatu dengan hakikat realitas yang nonlinear, nonmekanis, kreatif dan hidup. Selain itu, pembelajaran kontekstual mendorong mahasiswa untuk menemukan hubungan antara materi yang dipelajari dengan situasi dunia nyata. Mahasiswa dituntut untuk dapat menangkap hubungan antara pengalaman belajar di sekolah dengan kehidupan nyata dan mendorong mahasiswa untuk dapat menerapkannya dalam kehidupan. Bukan hanya mengharapkan mahasiswa dapat memahami materi yang dipelajarinya, akan tetapi bagai mana materi pelajaran itu dapat mewarnai prilakunya dalam kehidupan sehari-hari (Putri et al., 2018) Belajar dengan multikonteks membuat mahasiswa hasil belajar rendah termotivasi untuk belajar sehingga diduga dapat meningkatkan kemampuan berpikir kreatif mahasiswa. Sebab mahasiswa belajar dengan keadaan kondisi sehari-hari, sehingga pengetahuan yang diperolehnya semakin bermakna karena dapat diaplikasikan dalam 
801 Penerapan Model SAVI (Somatic, Audiotory, Visualition, Intellectual) dalam Meningkatkan Keterampilan Berpikir Kreatif Mahasiswa pada Pembelajaran Daring Prodi Administasi Rumah Sakit - Erpidawati, Silvia Adi Putri

DOI: https://doi.org/10.31004/edukatif.v4i1.1875

kehidupannya. Jika peningkatan kemampuan berpikir kreatif mahasiswa dengan hasil belajar rendah sudah cukup baik. Maka penerapan pembelajaran SAVI berinteraksi dengan hasil belajar artinya model pendekatan pembelajaran SAVI berjalan baik jika mahasiswa sebelumnya telah memiliki Hasil Belajar terhadap materi yang akan dipelajari.

\section{PENUTUP}

Hasil temuan ini dapat disimpulkan sebagai berikut Kemampuan berpikir kreatif mahasiswa yang belajar menggunakan model SAVI lebih baik daripada kemampuan berpikir kreatif mahasiswa yang belajar menggunakan model ekspositori. Kemampuan berpikir kreatif mahasiswa dengan hasil belajar tinggi yang belajar dengan menggunakan pendekatan SAVI lebih baik dari pada kemampuan berpikir kreatif mahasiswa dengan hasil belajar tinggi yang belajar dengan model ekspositori, kemampuan berpikir kreatif mahasiswa dengan hasil belajar rendah yang belajar dengan menggunakan pendekatan SAVI lebih baik daripada kemampuan berpikir kreatif mahasiswa dengan hasil belajar rendah yang belajar dengan model ekspositori. Tidak terdapat interaksi antara pendekatan SAVI dan hasil belajar mahasiswa dalam mempengaruhi kemampuan berpikir kreatif mahasiswa.

\section{UCAPAN TERIMA KASIH}

Terimakasih kami ucapkan kepada Kemeristek Dikti yang telah memberikan dana hibah sehingga pelaksanaan penelitian dapat dilaksanakan bukti luaran dari hasil penelitian berupa artikel ilmiah

\section{DAFTAR PUSTAKA}

Ahmad, F., Fitriani, F. L., \& Kurniawan, I. (2021). Independent Village Development. Proceedings Of The 2nd International Conference On Administration Science 2020 (ICAS 2020), 564(Icas 2020), 117-120. Https://Doi.Org/10.2991/Assehr.K.210629.022

Ainia, Q., Kurniasih, N., \& Sapti, M. (2012). Eksperimentasi Model Pembelajaran Auditory Intellectually Repetition (AIR) Terhadap Prestasi Belajar Matematika Ditinjau Dari Karakter Belajar Siswa Kelas VII SMP Negeri Se-Kecamatan Kaligesing Tahun 2011/2012. Kontribusi Pendidikan Matematika Dan Matematika Dalam Membangun Karakter Guru Dan Siswa, November, 978-979. Http://Eprints.Uny.Ac.Id/Id/Eprint/10079

Daharnis, W. R. Y. F. (2019). The Effect Of SAVI Model (Somatic, Auditory, Visualization, Intellectual) On Creative Thinking Skills Based On Student Learning In IV Class In Basic School. International Journal Of Science And Research (IJSR), $\quad 8(1), \quad 1764-1768$. Https://Www.Ijsr.Net/Archive/V8i1/ART20194623.Pdf

Dores ,S.Pd., M.Pd, O. J., Wibowo, D. C., \& Susanti, S. (2020). Analisis Kemampuan Berpikir Kritis Siswa Pada Mata Pelajaran Matematika. J-Pimat: Jurnal Pendidikan Matematika, 2(2), 242-254. Https://Doi.Org/10.31932/J-Pimat.V2i2.889

Erpidawati, E., \& Susanti, E. (2019). Kontribusi Pengelolaan Manajemen Kelas Terhadap Hasil Belajar Mahasiswa Fakultas Kesehatan Dan Mipa Universitas Muhammadiyah Sumatera Barat. Jurnal Benefita, 1(1), 70. Https://Doi.Org/10.22216/Jbe.V1i1.2405

Febrianti, Y., Djahir, Y., \& Fatimah, S. (2016). Analisis Kemampuan Berpikir Kreatif Peserta Didik Dengan Memanfaatkan Lingkungan Pada Mata Pelajaran Ekonomi Di SMA Negeri 6 Palembang. Jurnal Profit, 3(1), 121-127. Http;//Ejournal.Unsri.Ac.Id/Index.Php/Jp/Issue/View/591 
802 Penerapan Model SAVI (Somatic, Audiotory, Visualition, Intellectual) dalam Meningkatkan Keterampilan Berpikir Kreatif Mahasiswa pada Pembelajaran Daring Prodi Administasi Rumah Sakit - Erpidawati, Silvia Adi Putri

DOI: https://doi.org/10.31004/edukatif.v4i1.1875

Fitria, Y. (2019). Landasan Pembelajaran Sains Terintegrasi (Terpadu) Untuk Level Dasar (Issue 29). Https://Doi.Org/10.31227/Osf.Io/A4gdr

Handoko, H. (2017). Pembentukan Keterampilan Berpikir Kreatif Pada Pembelajaran Matematika Model SAVI Berbasis Discovery Strategy Materi Dimensi Tiga Jelas X. Edumal, 6(1), 85-95.

Haruminati, N. W. Y., Suarni, N. K., \& Sudarma, I. K. (2016). Pengaruh Model Pembelajaran SAVI Terhadap Minat Belajar Matematika Siswa Kelas IV SD Mutiara Singaraja. E-Journal PGSD Universitas Pendidikan Ganesha, 4(1), 1-11. Http://Ejournal.Undiksha.Ac.Id/Index.Php/JJPGSD/Article/Download/6982/4758

Hazal Fitri. (2015). Manajemen Pelaksanaan Pembelajaran Ict Di Sd Negeri 46 Kota Banda Aceh. Visipena Journal, 7(2), 184-195. Https://Doi.Org/10.46244/Visipena.V7i2.332

Novelti, N., Ramadhan, S., Ermanto, E., \& Agustina, A. (2018). Developing An Instructional Model Assisted Audio Visual Media. 263(Iclle), 111-116. Https://Doi.Org/10.2991/Iclle-18.2018.17

Perpres. (2003). Undang-Undang No 20 Tahun 2003 Tentang Sistim Pendidikan Nasional. Demographic Research, 49(0), 1-33: 29 Pag Texts + End Notes, Appendix, Referen.

Putri, A. R., Masniladevi, \& Desyandri. (2018). Pengaruh Penggunaan Metode Problem Solving Model Polya Terhadap Hasil Belajar Soal Cerita Di Sekolah Dasar The Effect Of Using Problem Solving Method With Polya Model To Students Learning Outcome About Narrative Story In Elementary School. EJournal Pembelajaran Inovasi, Jurnal Ilmiah Pendidikan Dasar, 6(2), 19-32. Http://Ejournal.Unp.Ac.Id/Students/Index.Php/Pgsd/Article/View/5734/3012

Rintonga, S. (2019). Efektivitas Penggunaan Model Pembelajaran Word Square Dengan Kemampuan Pemecahan Masalah Matematis Siswa Di Smp 9 Padangsidimpuan. Jurnal Mathedu, 2(3), 90-95.

Sanjaya, W. (2016). Strategi Pembelajaran. Prenada Media.

Shoimin, A. (2016). Model Pembelajaran Inovatif Dalam Kurikulum 2013. Ar-Ruzz.

Sulistiono, E., \& Yuni Sri Rahayu, Dan. (2014). Peningkatan Kemampuan Berpikir Kritis Siswa Menggunakan Perangkat Pembelajaran Ipa Smp Berorientasi Penyelesaian Masalah. Jurnal Pena Sains, $1(2)$. 